\title{
Theonome Reciprocity as Key for Interpreting the Phenomenon of Declining Numbers in Protestant Mainstream Churches - A South African Study
}

\author{
By Sophia van Helden ${ }^{*}$
}

\begin{abstract}
Declining of Protestant mainstream churches is observed worldwide. This tendency was studied in the light of theonome reciprocity: God's activities are integrated in believers' activities and believers' activities are driven by God's active will. The activity of the Afrikaans speaking Protestant mainstream believer in South Africa is part of a complex network of human factors. The only factor which can be addressed in order to establish possible change, is the way of thinking within the ecclesiology. If the principles engraved in the Great Commission become part of a believer's thinking, a Christ-centered paradigm ought to develop, resulting in God-willed deeds; deeds that will portray obedience to the Great Commission as God's will. A turnaround might result in God-willed thinking, consequently normalising the church practice and enhancing growth.
\end{abstract}

\section{Introduction}

The phenomenon of declining numbers within the Protestant mainstream churches is observed worldwide. ${ }^{1,2,3}$ Even the flourishing reformed churches in Korea have been experiencing decline since 1995. ${ }^{4}$ This paper focuses on the phenomenon of declining numbers within the Reformed Churches of South Africa (RCSA) $)^{5}$ and how it is approached in the light of theonome reciprocity.

* Extraordinary Lecturer, Unit for Reformed Theology, Northwest University, (Potchefstroom), South Africa.

1. Robyn Gill, The "Empty" Church Revisited (Ashgate: Burlington, 2003), 5, 6.

2. David Gilbert, "'Deep change' or 'slow death?' A practical road guide for the highway of change. A learning manual for church boards" (PhD thesis, Western Theological Seminary, 2004).

3. Andrew Walls, The Cross-cultural process in Christian history - Studies in the Transmission and Appropriation of Faith (Edinburgh: T \& T Clark, 2002), 9-54.

4. Chung-Dae Gwak and Jurgen Hendriks, "An interpretation of the recent membership decline in the Korean Protestant Church," Missionalia 29, no. 1 (2001).

5. Jurgen Hendriks, "Die Suid-Afrikaanse Godsdienstige landkaart aan die begin van die nuwe millennium: tendense in die eerste post-apartheid bevolkingsensus" ("The South African Religious map at the beginning of the new millennium: trends in the first postapartheid population census,") Praktiese Teologie in Suid-Afrika 15, no. 2 (2000). 


\section{Theonome Reciprocity}

Van Ruler, a reformed theologian who paid attention to the place of man in the church practice, showed great appreciation for human activity within this context, emphasizing man's autonomy, maturity, creativity and ability to cooperate according to God's plan. ${ }^{6}$ Theonome reciprocity refers to the Godman relationship. Van Ruler ${ }^{7}$ describes this relationship between the Holy Spirit and the human spirit as a "secret": Divine action (theonome) which makes human action possible to react according to the Divine will (Rom 8: 16) (reciprocity). In this relationship of theonome reciprocity the Spirit dwells in believers and man stays exactly who they are, but the Divine action takes place within these persons' actions. This presence of the Spirit differs in each person, each nation, each culture and each century. Man in time, in his willingness, openness and choices, is thus part of this "secret" combination of actions, called theonome reciprocity. 8,9

\section{Theonome Reciprocity and the Great Commission}

In Matt 28: 18-20 the Lord gave his last commission to the church. This Great Commission is grounded in the indicative and imperative of these verses. ${ }^{10}$ In 28: 18 the Lord proclaims his omnipotence (indicative) and this is affirmed by the second indicative (28: 20b), declaring his omnipresence. Between these two indicatives, the imperative is imbedded (28: 19-20a). The indicative focusses on God, while the imperative focusses on man. Consequently the imperative directs man's church practice activities in order to make disciples (28: 19b) by establishing external (28: 19a) and internal growth (28: 19c) as an unified system. ${ }^{11}$ By incorporating the broken, yet reborn believer, all things are implicitly mentioned, including decline.

6. Jac Rebel, Pastoraat in Pneumatologisch perspektief: een theologische verantwoording vanuit het denken van A.A. van Ruler (Chaplaincy in Pneumatologisch perspective: a theological justification from thinking of A.A. Ruler) (Kampen: Kok, 1981), 17, 74.

7. Arnold van Ruler, Theologisch werk. Deel I (Theological work. Part I) (Nijkerk: Callenbach, 1969), 181.

8. Ibid., 187.

9. Gerben Heitink, Practical Theology: History, Theory, Action Domains - Manual for Practical Theology, trans. and ed. Reinder Bruinsma (Michigan, Cambridge, UK: William B. Eerdmans Publishing Company, 1999), https://goo.gl/KsO0oS.

10. Ibid.

11. Coenie Burger, Gemeentes in transito - vernuwingsgeleenthede in 'n oorgangstyd (Churches in transit - innovation opportunities in a period of transition) (Kaapstad: Lux Verbi, 1995), 23-25. 
This structure of the Great Commission reveals the bipolar characteristic (God-man relationship) of theonome reciprocity. ${ }^{12}$ This "secret" relationship between God and man points to covenantal activity. According to Bosch, ${ }^{13}$ research regarding the Great Commission inevitably involves the covenant, which focusses on the activity of God and the activity of the believer. In short: God as missional God includes man in his mission, and being part of this mission, man's life is transformed according to God's will, thus doing what God intended with the result of glorifying God.

In the light of theonome reciprocity, the unstoppable thrust of God the Spirit is to be discussed, but also the inevitable involvement of believers within the phenomenon of declining churches as researched in the RCSA.

Discussing theonome reciprocity as a key for interpreting the phenomenon of declining numbers in Protestant mainstream churches, one must realize that this "secret" bipolar activity takes place within time and space ${ }^{3}$. The human part is limited, because brokenness causes lacking perfection. Since paradise this resulted in a restorted covenantal relashionship. This restorted relationship can be recognized where the Spirit is in a process of being extinguished. However, in spite of this human possibility, God the Spirit always finds new ways and keeps on moving according to the Divine will.

In order to explain theonome reciprocity in the South African context, the activity of God, as well as the activity of man, as factors in the declining phenomenon of churches, are discussed in this paper. The only human factor that can be addressed in order to introduce change, is the way man thinks. An unbalanced paradigm is reflected by an unbalanced church practice, and one of the ways in which this can be revealed, is when declining numbers reveal the imbalanced practice. The study conducted in the RCSA revealed unbalanced Scriptural thinking, thus portraying a terrain where the Spirit was extinguished gradually. This could only be changed by true repentance and turnaround, which is also dependent on Godly intervention.

Theonome reciprocity is a key for interpreting the declining tendency: The Spirit can use declining to work repentance in man, thus creating a turnaround towards Scriptural thinking and obedience to the Great Commission.

\section{The Activity of God}

God as missional God moves unstoppable, while the same purposeful zeal is expected of believers, being part of the covenant. ${ }^{14}$ This movement of

12. van Ruler, Theologisch werk. Deel I, 202, 203.

13. David Bosch, Transforming mission - Paradigm shifts in theology of mission (New York: Orbis Books, 1991), 24-317.

14. Ibid., 392. 
God to intervene in human history has been observed as evidence of God keeping His part of the covenant with people. We will now briefly discuss some of these waves, and also mention how God is still influencing our present time.

Equilizing wave: For the past 2000 years a wave manifests about every 500 years. The first pitch of a wave was noticed about $500 \mathrm{AD}$. This took place due to the decline of the Roman Empire and the start of the Dark Ages. The second wave reached its climax in 1054 when the Great Schism between Catholicism and Greek Orthodoxy took place. The third wave peaked in 1517 in Wittenberg at the start of the Protestant Reformation. The fourth wave is still in process and will be revealed sometime during the 21st century. ${ }^{15}$ Tickel emphasizes that it is important to realize that the $21^{\text {st }}$ century wave will generate transitions but not in a way that religion will be destroyed. On the contrary, it confirms the unstoppable force of the Spirit by which new ways of experiencing religion are created. Mainstream churches thus ought to acknowledge that they are in the present day amidst an inevitable transition. ${ }^{16}$

North-South wave: Historically Protestantism was situated in the developed countries of the northern hemisphere. From here the gospel spread, either by missionaries or colonization. For centuries enculturation of Christianity has taken place in the global southern hemisphere (South America, Africa south of the Sahara, Asia). Today, this movement flourishes within developing countries where indigenous churches interpret the gospel in a syncretistic and charismatic way, while the decreasing western orientated Protestant mainstream churches reveal a wave of stagnation, seemingly due to an inability to restructure according to Scripture ${ }^{17}$ (Rom 12: 2, Matt 9: 17, Matt 28: 18-20). At the same time, the Christian heartland has shifted to the global south, due to the secularization of the West.

Waves within congregations: In the life cycle of a congregation ${ }^{18}$ prosperous periods (societas waves) as well as periods of hardship (communitas waves) are recognized. It is also recognized as the "revolving-door syndrome"19 revealing periods of "advance and recession." Declining churches experience the communitas wave and whenever a turnaround takes place and numbers increase, a prosperous period. ${ }^{20,21,22}$

15. Phyllis Tickel, The great emergence (Michigan: Baker Books, 2008), 19-28.

16. Ben du Toit, God? Geloof in 'n postmoderne tyd (God? Faith in a postmodern time) (Bloemfontein: CLF-Uitgewers, 2000).

17. Walls, The Cross-cultural process, 73-80.

18. Martin Saarinen, The life cycle of a congregation (New York City: The Alban Institute, 1992).

19. David Barret, George Kurian and Harold Johnson, World Christian Encyclopedia. A comparative survey of churches and religions in the modern world, Volume 1 (Oxford: Oxford University Press, 2001), 19.

20. Saarinen, The life cycle of a congregation. 


\section{The Activity of Man}

The activity of man in the declining South African Protestant context, which includes the RCSA, is part of a complex and intertwined network of factors.

\section{Factors Difficult to Measure}

Change prevails in all levels of life. Especially since the Enlightenment era, critical thinking and scientific discoveries have influenced the way we view life. ${ }^{23}$ Questions that are asked by upcoming generations are not always answered satisfactorily and the integrity, credibility and relevance of the existing church are often questioned. ${ }^{24}$

Other difficult measureable factors are secularism, decline in knowledge of God, globalism, pluralism, materialism, individualism, as well as the restructuring process of thinking within a shattered postmodern society, resulting in a subjective lifestyle..$^{25,26,27}$

This subjective lifestyle results into two distinguishable groups, namely those who find refuge in closeness and those who find freedom in openness. ${ }^{28,29}$ The South African Protestant group is part of the conservative group, projecting introversion and lack of adaptability. An observation has also been that those members that are less conservative increasingly join other denominations, ${ }^{30}$ or choose to not belong to any specific church at all. ${ }^{31}$

21. Rein Brouwer et al., Levend liggaam: Dynamiek van christelijke geloofsgemeenschappen in Nederland (Living body: Dynamics of Christian denominations in the Netherlands) (Kampen: Kok, 2007), 16-20.

22. Burger, Gemeentes in transito - vernuwingsgeleenthede.

23. Bosch, Transforming mission - Paradigm shifts.

24. B. du Toit, God? Geloof in 'n postmoderne tyd.

25. Gill, The "Empty" Church Revisited, 17.

26. Tickel, The great emergence, 50 .

27. Nelus Niemandt, Nuwe drome vir nuwe werklikhede (New dreams for new realities) (Wellington: Lux Verbi. BM, 2007), 22.

28. Walls, The Cross-cultural process, 274.

29. Kevin Ward, "Is New Zealand's future churchless?," Stimulus 12, no. 2 (2004): 3.

30. Tickel, The great emergence, 51.

31. Ward, "Is New Zealand's future churchless?," 11. 


\section{Measurable Factors}

Depopulation and urbanization are clear phenomena in the tendency of declining churches, while statistics of the past three decades also indicate a decline in the birth rate which have a direct effect on numbers. ${ }^{32,33}$

Economic, political and social factors are intertwined and are seen as major causes for decline in South Africa. Thousands left the country since 1994 because of affirmative action in the work place, ${ }^{34}$ lack of security, as well as the inability to control crime. ${ }^{35}$ In fact, a whole generation Afrikaans speaking Protestant members emigrated between 1994 and 2006. ${ }^{36,37}$

Many church members were displaced by the political change in 1994, experiencing a peripheral shift in society. This alienation resulted in a shift to the privacy of the home where believers could assert themselves by means of the internet and globalisation. The church, the Bible and family life were replaced by technology. ${ }^{38,39}$ This affected family life drastically. Religious values and rituals were replaced by each family member's own individual experience in his/her isolation. This is worsened by the absence of parents due to the claims of modern materialistic life. ${ }^{40}$

The primary social structure and socializing processes experience wavering, thus affecting Protestant living and churches in a negative way. ${ }^{41,42,43,44}$ Sociologists affirm that inadequate transfer of religious life usually

32. Herman Giliomee, Die Afrikaners 'n Biografie (The Africans' Biography) (Kaapstad: Tafelberg, 2004), 540.

33. Jurgen Hendriks, "Die 1991-bevolkingsensus-tendense en die Afrikaanse kerke" ("The 1991 population census trends and African churches,") Nederduits Gereformeerde Teologiese Tydskrif 34 no. 4 (1993).

34. Brouwer et al., Levend liggaam: Dynamiek van christelijke, 40-47.

35. Giliomee, Die Afrikaners 'n Biografie, 633.

36. John Kane-Berman, South Africa Survey 2006/2007 (Braamfontein: South Africa Institute of Race Relations (SAIRR), 2007).

37. Peet van Aardt, "Hele geslag wit mense verlaat SA" ("Whole family whites leave SA,") Rapport no. 4, 24 Sep. (2006).

38. Johannes Erasmus and Jurgen Hendriks, "Religious affiliation in South Africa early in the new millennium: Markinor's World Values Survey," Journal of Theology for Southern Africa 117 (2003).

39. Tickel, The great emergence, 60-64.

40. Elsie Buchner, "Geld, besittings gawe van God" ("Money, possessions gift of God") Beeld 3 Sep. (2007): 12.

41. Helena Cameron et al., Studying local churches: A handbook (London: SCM Press, 2005), 54.

42. Annika Dreyer, "Hoe begin mens oor?" ("How to get started on?,") Beeld 13 Jan. (2009): 13.

43. Isak Olivier, "The strategic task of the church in creating spaces for spirituality" (PhD thesis, Northwest-University Potchefstroom Campus, 2006), 37. 
demonstrated by parents, as well as the generation gap, directly lead to declining numbers. ${ }^{45,46,47}$ When discussing characteristics of the Afrikaner as part of the Protestant mainstream churches in South Africa, individualism, reservedness and pedantry ought to be.48,49,50,51 These manifestations emphasize lack of conformity and leadership, as well as lack of servicemindedness towards Africa. ${ }^{52}$ It portrays the absence of collective thinking directed by Godly calling. However, one strong positive characteristic which often emerged historically, is that a mysterious vitality is revealed when extermination of the Afrikaner-group seems to be at hand. ${ }^{53}$

Added to these factors is that the South African mainstream believer demonstrates a double history. ${ }^{54}$ As first world descendants they have lived in Africa for more than 350 years. Since 1994, however, South Africa has been forwarded as a developing third world country, which is observed by these first world descendants in a cynical way. The real changing South African context is dealt with at a distance. Nowadays guidance from the church, which directed believers incorrectly through the years of apartheid, is therefore not easily accepted and the ignorance regarding the reality of the $21^{\text {st }}$ century South Africa, is therefore strenghthened. $5,56,57,58,59,60,61,62$

44. Magda Rall, "Ondersoek wys rekenaar, TV neem plek van Bybel" ("Research has shown that computer, TV takes place Bible,") Beeld 2 Oct. (2007): 12.

45. Bob Altemeyer, "The decline of organized religion in Western civilization," International Journals for the Psychology of Religion 14, no. 2 (2004).

46. Alasdair Crockett and David Voas, "Generations of decline: religious change in 20th-century Britain," Journal for the Scientific Study of Religion 45, no. 4D (2006).

47. Lize Stilma, Op zoek naar de oorzaken van kerkverlating (Searching for the causes of church desertion) (Baarn: Ten Have, 1988).

48. Hendriks, "Die Suid-Afrikaanse Godsdienstige landkaart.

49. Giliomee, Die Afrikaners 'n Biografie, 646.

50. Filippus du Toit et al., Moeisame pad na vernuwing: Die NG Kerk se pad van isolasie en die soeke na 'n nuwe relevansie (Arduous road to renewal: The DRC's road of isolation and the search for a new relevance) (Bloemfontein: Barnabas, 2002), 8-12.

51. Gert Jordaan, "Afrikaanse gelowiges geroep om saam te staan" ("Called African Christians to stand together,") Die Kerkblad 110, no. 3211 (2008): 10-11.

52. Anne Fraker and Larry Spears, The private writings of Robert K. Greenleaf Seeker and servant reflections on religious leadership (San Francisco: Jossey-Bass Publishers, 1996), 179.

53. Giliomee, Die Afrikaners 'n Biografie, 663.

54. Hendrik van Coller, Perspektief en Profiel Deel 3 (Perspective and Profile Part 3) (Pretoria: Van Schaik Uitgewers, 2007), 55-59.

55. Walls, The Cross-cultural process, 277.

56. Niemandt, Nuwe drome vir nuwe werklikhede, 40.

57. Giliomee, Die Afrikaners 'n Biografie.

58. Erasmus and Hendriks, "Religious affiliation in South Africa."

59. Cameron et al., Studying local churches:, 62.

60. Olivier, "The strategic task of the church, 38. 
Finally, the church practice portrays human activity resulting from human thinking. Whenever a church practice displays an imbalance in internal and external growth (re Great Commission), the frame of thinking can be determined either as an I-paradigm (Institutionalistic) or a S-paradigm (Spiritualistic), instead of a Chistocentric paradigm. ${ }^{63}$ Research conducted in some congregations in the Reformed Church of South Africa ${ }^{64}$ indicated that the determining factor for the crisis in the church practice, is the presence of the unbalanced I-paradigm.

There are always two poles in any paradigm, namely the static and the dynamic poles. Imbalance manifests when one of these poles dominate. Research indicated that the static pole dominates mainstream congregations. ${ }^{65}$ These churches were seemingly unaware of this unbalanced situation. Sola Scriptura was traditionally regarded as these churches' strong point, thus considering the church practice as "beyond question."66 Seeing that the Great Commission was not emphasized according to the missional principles of internal and external growth in a unified system, this seemingly strong point, was altered to become the weak point, furthering decline. ${ }^{67,68,69,70}$ Furthermore, formalism and rationalism forthcoming from the I-paradigm, dominated these church practices. The absence of interpreting these signs pro-actively caused the communitas wave to be experienced as highly disruptive.

61. F. du Toit et al., Moeisame pad na vernuwing:, 39.

62. Erna Oliver, "Thoughts on writing Afrikaner church history in the 21st century," Studia Historiae Ecclesiasticae xxxiii no. 1 (2007).

63. Crockett and Voas, "Generations of decline: religious change.

64. Sophia van Helden, 'n Hermeneuties-empiriese strategie rakende die verskynsel van kerkkrimping in tradisioneel Afrikaanse "susterkerke" in Suid-Afrika 'n prakties-teologiese studie (A Hermeneutic-empirical strategy regarding the phenomenon of declining in traditional African "sister churches" in South Africa - a practical theological study) (PhD thesis, Northwest-University Potchefstroom Campus, 2010), 263-350.

65. Ibid.

66. Christian Schwarz, Paradigm shift in the church - How natural church development can transform theological thinking (Emmelsbüll: Church Smart Resources, 1999), 7.

67. Burger, Gemeentes in transito - vernuwingsgeleenthede.

68. Jan van Rooy, "Ons sendingerfenis ... en die vrugte na 100 jaar" ("Our mission heritage ... and the fruit after 100 years,") Die Kerkblad Sep. (2006): 21, 22.

69. Koos van Rooy, "Sendingwerk in die toekoms ... Hoe en waarheen?" ("Missionary work in the future ... How and where?,") Die Kerkblad Apr. (2007): 30-32.

70. Bennie van der Walt, "Die Postmodernisme, 'n verleentheid en 'n geleentheid" ("Postmodernism, an embarrassment and an opportunity) Die Kerkblad Sep. (2006): 30-32. 


\section{I-paradigm and the RCSA-ecclesiology}

Research was conducted in the RCSA to determine the influence of thinking (according to the I-paradigm) as factor in the declining tendency. Thinking is at stake when the unified system of internal and external growth, according to the Great Commission, displays. ${ }^{71,72,73}$ The RCSA-study indicated that the static pole indeed dominated these mainstream congregations. ${ }^{74}$

The above mentioned factors of God's activity and man's activity, lead to only one factor which can be humanly addressed in order to establish a possibility of a turnaround and growth. This factor is the believer's thinking within the church practice. When human thinking and turnaround are in question, theonome reciprocity and covenental activity are the key to start the process of interpretation. According to Rom 12: 2, God commands the believer to be transformed by the renewing of his/her mind. When man does renew his mind, it reveals that God initiated this transformation in man's subconscience before man becomes willing to change. Exegesis of Rom 12: 2 shows that the indicative and the imperative are structurally the same as Matt 28: 16-20. Theonome reciprocity, true to covenantal activity, is to be recognized and embraced as key in this communitas wave of declining. ${ }^{75}$

Research conducted in certain RCSA congregations between 2005 and 2008 thus focused on the believer's paradigm regarding the church practice. The unified system of internal (qualitative) and external (quantitative) growth, as prescribed in the Great Commission, were applied in determining whether thinking in the RCSA was indeed practiced according to the imbalanced Iparadigm, in contrast to a Scriptural Christocentric paradigm. The framework for the research entailed eight aspects present in church practices, ${ }^{76}$ namely spirituality, ministry, worship, small groups, evangelising, structures, leadership and relationships. Some conclusions of the study will be discussed in the following paragraphs, emphasizing the need to transform thinking in mainstream churches.

Spirituality: Spirituality focuses on the presence of the activity of God in the believer's daily existance. ${ }^{77}$ Doctrine, accompanied by rationality, forms

71. Walls, The Cross-cultural process.

72. Bosch, Transforming mission - Paradigm shifts.

73. Schwarz, Paradigm shift in the church, 9.

74. van Helden, 'n Hermeneuties-empiriese strategie rakende.

75. Philippa Strong, "Romans 12:2 as an important paradigm for transformation in a Christian: a practical theological study," (PhD thesis, Northwest-University Potchefstroom Campus, 2007), 52-59.

76. Christian Schwarz, Natural Church Development: A guide to eight essential Qualities of Healthy churches (Randhart: S.A. Church Wise, 2000).

77. Arnold Smit, Gemeente en bediening 4 Nuut gedink oor leierskap in gemeentes. Die begeleiding van 'n Christelike geloofsgemeenskap (Church and ministry 4 Revisiting 
the central part of spirituality in the RCSA. Very little passion is thus demonstrated.78,79 Traditionally doctrinal dominated institutions functioned greatly according to rules, which strengthened the sense of being "beyond question" as mentioned earlier. The changes that have taken place in the past 20 years in South Africa have brought about changes in spirituality also; traditional ways of spirituality - perhaps more associated with personal piety and good reformed practices - have given way to new ways of spirituality, that typically place a stronger emphasis on passionate religious experience by means of a subjective relationship with Christ. ${ }^{80,81}$

Ministry: Traditional mainstream ministry is practised by office. According to Rom 12: 4-8, Ef 4: 11-16 and I Cor 12: 27: 31, each member is gifted and ought to let the congregation benefit from this. ${ }^{82}$ Absence of a giftorientated ministry lead to imbalances described as comfortableness, mediocracy, closedness, lack of courage and commitment, fear of fallacy, attachment to be in control, the burnout of the pastor (which can result in laying down the calling), as well as ignorance regarding church growth and being a servant believer. $83,84,85,86$ The results of the RCSA-research indicated that the ministry focused only on the offices of the pastor, elders and deacons. The utilisation of Spiritual gifts and the empowering of members as part of the ministry were not prioritised. Whilst the office of the believer received very high priority, it was not necessarily put to practice in the church practice.

Worship: The activity of the Spirit during worship can never be regarded as self-evident, for the Word is solely alive when God wants to work in a specific terrain. ${ }^{87,88}$ Being part of an incomplete world, the danger exists that the calling to let God speak, is also done in an incomplete way. Therefore the pastor ought to prepare inspirational liturgy and preach enthusiastically, thus

leadership in churches. The guidance of a Christian religious community) (Kaapstad: Lux Verbi, 1995), 24.

78. F. du Toit et al., Moeisame pad na vernuwing:, 48.

79. van Helden, 'n Hermeneuties-empiriese strategie rakende.

80. Tickel, The great emergence, 104-115, 123.

81. Olivier, "The strategic task of the church, 84-120.

82. Tjaart van der Walt, Die Messias het gekom! 'n Gids in die Evangelies vir toegewyde Bybelstudente (The Messiah has come! A guide in the Gospels for serious Bible students) (Potchefstroomse Teologiese Publikasies, 2007), 168.

83. Burger, Gemeentes in transito - vernuwingsgeleenthede.

84. Niemandt, Nuwe drome vir nuwe werklikhede, 53.

85. K. van Rooy, "Sendingwerk in die toekoms.

86. B. van der Walt, "Die Postmodernisme, 'n verleentheid en 'n geleentheid."

87. Schwarz, Paradigm shift in the church, 117.

88. Lambert Floor, Hy wat met die Heilige Gees doop (He who baptizes with the Holy Spirit) (Pretoria: N.G. Kerkboekhandel, 1979), 123. 
reflecting a living relationship with God. ${ }^{99}$ Adding heavy language, legalism and intellectualism are strengthened. ${ }^{90}$ In spite of such stumble blocks noticed in other mainstream denominations, research amongst the RCSA congregations indicated that ministers put much effort into preparing a service, but preferred to follow a strict, traditional liturgical order. Although ministers preached enthusiastically, the same enthusiasm was not always shared by the congregation. Whenever worship took place, Scripture was central and the atmosphere was highly sacred and dignified. Modernisation of the service and implementing the most recent form of the spoken language, were not regarded as important.

Small Groups: The human need to be part of an intimate group where holistic ministry within the unified system of internal and external growth (Great Commission) can take place, becomes all the more popular. ${ }^{91,92}$ The lack of small group ministries indicates lack of leadership, empowered members, evangelising, Bible knowledge and gifts. ${ }^{93,94}$ Research conducted in the RCSA indicated that the term, small groups, was unfamiliar. Contradictory, the term, Biblestudy groups, was familiar in church language. This portrayed closedness, focussing on internal growth. Groups amongst the youth, senior members and ladies focused on their own goals, thus ignoring a holistic and missional approach.

Evangelization: A need-oriented church focussing on the community, is unknown where the I-paradigm dominates. ${ }^{95,96}$ According to Keller, ${ }^{97}$ mainstream churches are very effective in preventing church development and churchplanting in their direct environment. Growth cannot take place naturally, for the terrain for organic growth is not healthy and not nurtured according to the principles laid down by the Great Commission. ${ }^{8}$

Research in the RCSA indicated that evangelization was regarded as the task of a committee. ${ }^{99}$ Evangelization, where each member would be involved,

89. Rick Warren, Doelgerigte kerk (Purposeful church) (Kaapstad: Struik Christelike Boeke, 2005), xvi.

90. Marinus Wijnbeek, "Gelowig in 2050?" ("Faithful in 2050?,") Die Kerkblad Oct. (2006): 33.

91. Brouwer et al., Levend liggaam: Dynamiek van christelijke, 105.

92. Strong, "Romans 12:2 as an important paradigm, 107-110.

93. F. du Toit et al., Moeisame pad na vernuwing:

94. Schwarz, Paradigm shift in the church, 171.

95. Walls, The Cross-cultural process.

96. J. van Rooy, "Ons sendingerfenis ... en die vrugte na 100 jaar."

97. Johan Kommers, "Opwekking binnen de traditioneel-reformatorische kerken: over oprecht verlangen en grote verlegenheid" ("Revival in the traditional-Reformation churches on sincere desire and great embarrassment,") In Luce Verbi 40, no. 4 (2006).

98. Walls, The Cross-cultural process.

99. van Helden, 'n Hermeneuties-empiriese strategie rakende. 
was totally absent. Though, the term, evangelization, was well known, meaning that those who fell out of church, ought to be sought. When found their social and physical needs ought to be cared for. In this way they could be brought back to church. They also assumed that the Word ought to be brought to the godless in other far countries. The absence of evangelization and the stereotypical thinking regarding evangelization, focused on the absence of missional obedience.

Structures: All types of structures are the result of human thinking. ${ }^{100}$ Imbalance comes to the fore when structures are regarded as principles. Ineffective structures ought to be changed to be functional. ${ }^{101}$ The power of institutional structures lie in the security it provides the congregation. Bound to set structures, flexibility is prevented and adaptation delayed. Due to depopulation and urbanization, the RCSA in the rural areas still make use of their big churches full of empty seats. Research indicated that the church building, as a physical structure, was seen as a symbol reflecting positive values. The church grounds were seen as the centre for church projects (internal growth), but not for projects with missional aims (external growth). Ministerial structures were set traditional ways which provided reassurance to the members.

Leadership: Church leadership is a service done by people in order to guide their fellowman in the ways of the Lord.102 Therefore all services start with human thinking. ${ }^{103}$ Eph 4: 12 states that believers ought to be empowered for their service. Often tension exists between God's plan and the formulation of the congregation's plan. This indicates lack of practised thinking and obedience in the ways of the covenant. ${ }^{104,105}$ The absence of spirit-filled leaders results in shaky leadership, ${ }^{106}$ which leads to shortcomings in the ministry. ${ }^{107}$ Research in the RCSA indicated that the minister was seen as the main leader who ought to know everything that was going on in the congregation, while others in office were not automatically accepted as leaders. Women were leaders in congregational projects, while men guided the congregation in

100. Michiel Schalekamp, "Missiones Ecclesiae: 'n missionêre visie en strategie in gemeentebou ten opsigte van multikulturele kerkplanting" ("Missiones Ecclesiae: a missional vision and strategy for congregational growth regarding multicultural church planting,") (PhD thesis, Northwest-University Potchefstroom Campus, 2005), 23-25.

101. B. van der Walt, "Die Postmodernisme, 'n verleentheid en 'n geleentheid."

102. Burger, Gemeentes in transito - vernuwingsgeleenthede.

103. Olivier, "The strategic task of the church, 141.

104. Burger, Gemeentes in transito - vernuwingsgeleenthede.

105. Warren, Doelgerigte kerk, 176.

106. Ibid.

107. Alan Roxburgh and Fred Romanuk, The missional Leader (San Fransisco: JosseyBass, 2006). 
spiritual matters. Missional and empowering leadership were regarded as relative matters.

Relations: If church members do not build loving relations through sacrifice, self denial and faith, the warm head and cold heart syndrome, typical to an I-paradigm, is revealed. ${ }^{108}$ Lack of loving relations and loving deeds affect the congregational atmosphere, friendliness, involvement, mutual visits and hospitality. Imbalance in relationships manifests in differences, groupings, quarrels and intolerance. The amount of energy put into a congregation projects the level of congregational identity. ${ }^{109,110}$ Research in the RCSA indicated that relationships reflected mutual respect, patience and fellowship. Friendliness towards outsiders though was regarded as a relative matter indicating the lack of missional intentions.

Each of these eight ecclesiological aspects reveals the imbalance in the RCSA due to the existing I-paradigm where static aspects dominate. Understanding the effect of the imbalance in the unified system, being a changeable factor in the declining tendency, ought to encourage believers to engage in serious introspection. A turnaround applying Christocentric and covenantal thinking can result in deep change, knowing that the key and all hope lie in theonome reciprocity.

The utilisation of Spiritual gifts and the empowering of members as part of the ministry were not prioritised. Whilst the office of the believer received very high priority, it was not necessarily put to practice in the church practice.

\section{Turnaround}

A second research study was conducted among the 2012 RCSA-Synod delegates to determine the degree of awareness regarding the crisis. The questionnaire also focused on the possibility of a shift in thinking towards the demands of the Great Commission, as well as whether the entire South African population, regardless of language and culture, would be regarded as the target group in case a change in thinking would exist. ${ }^{111}$

Two days after the questionnaire was completed, thus before any results were known, the RCSA-Synod decided in favour of a turnaround towards the demands of the Great Commission. ${ }^{112}$ The results of the study received later,

108. Wijnbeek, "Gelowig in 2050?," 34.

109. Burger, Gemeentes in transito - vernuwingsgeleenthede.

110. Olivier, "The strategic task of the church.

111. Sophia van Helden, "Verskuiwende denke van die 2012-GKSA-Sinode" ("Moving thinking of the 2012 GKSA Synod") In Luce Verbi 47, no. 1 (2013): 53.

112. Gereformeerde Kerke in Suid-Afrika, Acta - Handelinge van die tweede algemene sinode te Potchefstroom op 4 Januarie 2012 en volgende dae (Acta - Acts of the 
supported this decision, but indicated that church councils have not formulated decisions to confirm this mindshift yet. Results also indicated that growth could only take place if the South African population in its diversity, is evangelized.

Theonome reciprocity can be recognised as a key explaining this occurrence in the RCSA. A deliberate change in thinking, formulated as a Synod decision, is a sign that the Spirit initiated change in thinking over a long period before the delegates acted towards change.

\section{Conclusion}

Although man's thinking is only one factor in the complex phenomenon of declining churches, it appears to be a major factor to establish change resonating in the other factors. Theonome reciprocity as key for interpreting the declining crisis, can guide believers to persist to act in focused action, knowing that it is indeed Divine action that makes human action possible. Thus, when man starts reacting in favour of change back to Scriptural principles, it signals that the Spirit was already "secretly" at work, creating the change to the salvation of man and to the glory of God.

\section{Bibliography}

Altemeyer, Bob. "The decline of organized religion in Western civilization." International Journals for the Psychology of Religion 14, no. 2 (2004): 77-89.

Barret, David, George Kurian, and Harold Johnson. World Christian Encyclopedia. A comparative survey of churches and religions in the modern world, Volume 1. Oxford: Oxford University Press, 2001.

Bosch, David. Transforming mission - Paradigm shifts in theology of mission. New York: Orbis Books, 1991.

Brouwer, Rein, Kees de Groot, Henk de Roest, Erik Sengers, and Sake Stoppels. Levend liggaam: Dynamiek van christelijke geloofsgemeenschappen in Nederland (Living body: Dynamics of Christian denominations in the Netherlands). Kampen: Kok, 2007.

Buchner, Elsie. "Geld, besittings gawe van God" ("Money, possessions gift of God"). Beeld 3 Sep. (2007).

second general synod in Potchefstroom on January 4, 2012 and following days) (Pretoria: V \& R Drukkery, 2012). 
Burger, Coenie. Gemeentes in transito - vernuwingsgeleenthede in 'n oorgangstyd (Churches in transit - innovation opportunities in a period of transition). Kaapstad: Lux Verbi, 1995.

Cameron, Helena, Philip Richter, Douglas Daviesand, and Francis Ward. Studying local churches: A handbook. London: SCM Press, 2005.

Crockett, Alasdair, and David Voas. "Generations of decline: religious change in 20th-century Britain." Journal for the Scientific Study of Religion 45, no. 4D (2006): 567-584.

Dreyer, Annika. "Hoe begin mens oor?" ("How to get started on?.") Beeld 13 Jan. (2009).

du Toit, Ben. God? Geloof in 'n postmoderne tyd (God? Faith in a postmodern time). Bloemfontein: CLF-Uitgewers, 2000.

du Toit, Filippus, Hendrik Hofmeyr, Pieter Strauss, and Johan van der Merwe. Moeisame pad na vernuwing: Die NG Kerk se pad van isolasie en die soeke na 'n nuwe relevansie (Arduous road to renewal: The DRC's road of isolation and the search for a new relevance). Bloemfontein: Barnabas, 2002.

Erasmus, Johannes, and Jurgen Hendriks. "Religious affiliation in South Africa early in the new millennium: Markinor's World Values Survey." Journal of Theology for Southern Africa 117 (2003): 80-96.

Floor, Lambert. Hy wat met die Heilige Gees doop (He who baptizes with the Holy Spirit). Pretoria: N.G. Kerkboekhandel, 1979.

Fraker, Anne, and Larry Spears. The private writings of Robert K. Greenleaf Seeker and servant reflections on religious leadership. San Francisco: Jossey-Bass Publishers, 1996.

Heitink, Gerben. Practical Theology: History, Theory, Action Domains - Manual for Practical Theology. Translated and Edited by Reinder Bruinsma. Michigan, Cambridge, UK: William B. Eerdmans Publishing Company, 1999. https://goo.gl/KsO0oS.

Hendriks, Jurgen. "Die Suid-Afrikaanse Godsdienstige landkaart aan die begin van die nuwe millennium: tendense in die eerste post-apartheid bevolkingsensus" ("The South African Religious map at the beginning of the new millennium: trends in the first post-apartheid population census.") Praktiese Teologie in Suid-Afrika 15, no. 2 (2000): 73-97.

__. "Die 1991-bevolkingsensus-tendense en die Afrikaanse kerke" ("The 1991 population census trends and African churches.") Nederduits Gereformeerde Teologiese Tydskrif 34 no. 4 (1993): 542-551.

Gereformeerde Kerke in Suid-Afrika. Acta - Handelinge van die tweede algemene sinode te Potchefstroom op 4 Januarie 2012 en volgende dae (Acta - Acts of the second general synod in Potchefstroom on January 4, 2012 and following days). Pretoria: V \& R Drukkery, 2012.

Gill, Robyn. The "Empty" Church Revisited. Ashgate: Burlington, 2003. 
Gilbert, David. "'Deep change' or 'slow death'? A practical road guide for the highway of change. A learning manual for church boards." PhD thesis, Western Theological Seminary, 2004.

Giliomee, Herman. Die Afrikaners 'n Biografie (The Africans' Biography). Kaapstad: Tafelberg, 2004.

Gwak, Chung-Dae, and Jurgen Hendriks. "An interpretation of the recent membership decline in the Korean Protestant Church." Missionalia, 29, no. 1 (2001): 55-68.

Jordaan Gert. "Afrikaanse gelowiges geroep om saam te staan" ("Called African Christians to stand together.") Die Kerkblad 110, no. 3211 (2008).

Kane-Berman, John. South Africa Survey 2006/2007. Braamfontein: South Africa Institute of Race Relations (SAIRR), 2007.

Kommers, Johan. "Opwekking binnen de traditioneel-reformatorische kerken: over precht verlangen en grote verlegenheid" ("Revival in the traditionalReformation churches on sincere desire and great embarrassment"). In Luce Verbi 40, no. 4 (2006): 667-690.

Niemandt, Nelus. Nuwe drome vir nuwe werklikhede (New dreams for new realities). Wellington: Lux Verbi. BM, 2007.

Olivier, Isak. "The strategic task of the church in creating spaces for spirituality." PhD thesis, Northwest-University Potchefstroom Campus, 2006.

Oliver, Erna. "Thoughts on writing Afrikaner church history in the 21st century." Studia Historiae Ecclesiasticae xxxiii no. 1 (2007): 23-40.

Rall, Magda. "Ondersoek wys rekenaar, TV neem plek van Bybel" ("Research has shown that computer, TV takes place Bible.") Beeld 2 Oct. (2007).

Rebel, Jac. Pastoraat in Pneumatologisch perspektief: een theologische verantwoording vanuit het denken van A.A. van Ruler (Chaplaincy in Pneumatologisch perspective: a theological justification from thinking of A.A. Ruler). Kampen: Kok, 1981.

Roxburgh, Alan, and Fred Romanuk, The missional Leader. San Fransisco: Jossey-Bass, 2006.

Saarinen, Martin. The life cycle of a congregation. New York City: The Alban Institute, 1992.

Schalekamp, Michiel. "Missiones Ecclesiae: 'n missionêre visie en strategie in gemeentebou ten opsigte van multikulturele kerkplanting" ("Missiones Ecclesiae: a missional vision and strategy for congregational growth regarding multicultural church planting.") $\mathrm{PhD}$ thesis, NorthwestUniversity Potchefstroom Campus, 2005.

Schwarz, Christian. Paradigm shift in the church - How natural church development can transform theological thinking. Emmelsbüll: Church Smart Resources, 1999.

_.. Natural Church Development: A guide to eight essential Qualities of Healthy churches. Randhart: S.A. Church Wise, 2000. 
Smit, Arnold. Gemeente en bediening 4 Nuut gedink oor leierskap in gemeentes. Die begeleiding van 'n Christelike geloofsgemeenskap (Church and ministry 4 Revisiting leadership in churches. The guidance of a Christian religious community). Kaapstad: Lux Verbi, 1995.

Stilma, Lize. Op zoek naar de oorzaken van kerkverlating (Searching for the causes of church desertion). Baarn: Ten Have, 1988.

Strong, Philippa. "Romans 12:2 as an important paradigm for transformation in a Christian: a practical theological study." PhD thesis, NorthwestUniversity Potchefstroom Campus, 2007.

Tickel, Phyllis. The great emergence. Michigan: Baker Books, 2008.

van Aardt, Peet. "Hele geslag wit mense verlaat SA" ("Whole family whites leave SA.") Rapport no. 4, 24 Sep. (2006).

van Coller, Hendrik. Perspektief en Profiel Deel 3 (Perspective and Profile Part 3). Pretoria: Van Schaik Uitgewers, 2007.

van der Walt, Bennie. "Die Postmodernisme, 'n verleentheid en 'n geleentheid" ("Postmodernism, an embarrassment and an opportunity.") Die Kerkblad Sep. (2006).

van der Walt, Tjaart. Die Messias het gekom! ' $n$ Gids in die Evangelies vir toegewyde Bybelstudente (The Messiah has come! A guide in the Gospels for serious Bible students). Potchefstroomse Teologiese Publikasies, 2007.

van Helden, Sophia. 'n Hermeneuties-empiriese strategie rakende die verskynsel van kerkkrimping in tradisioneel Afrikaanse "susterkerke" in Suid-Afrika - 'n prakties-teologiese studie (A Hermeneutic-empirical strategy regarding the phenomenon of declining in traditional African "sister churches" in South Africa - a practical theological study). PhD thesis, Northwest-University Potchefstroom Campus, 2010.

"Verskuiwende denke van die 2012-GKSA-Sinode" ("Moving thinking of the 2012 GKSA Synod.") In Luce Verbi 47, no. 1 (2013).

van Rooy, Jan. "Ons sendingerfenis ... en die vrugte na 100 jaar" ("Our mission heritage ... and the fruit after 100 years.") Die Kerkblad Sep. (2006).

van Rooy, Koos. "Sendingwerk in die toekoms ... Hoe en waarheen?" ("Missionary work in the future ... How and where?.") Die Kerkblad Apr. (2007).

van Ruler, Arnold. Theologisch werk. Deel I (Theological work. Part I). Nijkerk: Callenbach, 1969.

Walls, Andrew. The Cross-cultural process in Christian history - Studies in the Transmission and Appropriation of Faith. Edinburgh: T \&T Clark, 2002.

Ward, Kevin. "Is New Zealand's future churchless?." Stimulus 12, no. 2 (2004).

Warren, Rick. Doelgerigte kerk (Purposeful church). Kaapstad: Struik Christelike Boeke, 2005.

Wijnbeek, Marinus. "Gelowig in 2050? ("Faithful in 2050?.") Die Kerkblad Oct. (2006). 
